\title{
MODEL PRACTICE OF PEDAGOGICAL REASONING AND ACTION TEACHING IN THE SECONDARY SCHOOL PHYSICAL EDUCATION TEACHERS IN SELANGOR
}

\author{
Mohamed Faizul Mat Som ${ }^{\text {a*, Muhammad Seman }}{ }^{\text {, }}$ Muhammad Faizal A. Ghani ${ }^{\mathrm{c}}$ \\ $a^{*}$ University of Malaya Kuala Lumpur \\ First affiliation address, City, Malaysia, faizu15152@yahoo.com \\ ${ }^{\mathrm{b}}$ University of Malaya \\ Kuala Lumpur Malaysia \\ ${ }^{c}$ University of Malaya \\ Kuala Lumpur, Malaysia mdfaizal@um.edu.my
}

\begin{abstract}
This study aims to determine the extent of the practice using a survey method in questionnaires, with 580 samples taken from the teachers who teach physical education subjects. This study determines the degree of correspondence model of reasoning practice pedagogy, focusing on dimensions of understanding, transformation and teaching as eksogen variable. While on the other hand dimension of evaluation, reflection and understanding a new is practice action teaching teachers as endogen variable. This study uses the Structural Equation Modeling analysis method (SEM), where the findings explain the testing Goodness of Fit Chi Square with degrees of freedom which is 53, CMIN/DF 111.298 is 2.100 (<5), Comparative Fit Index (CFI) ialah .993 (> . 90), Tucker Lewis Index (TLI) is 989. (>. 90. While the Root Mean Square Error of Approximation (RMSEA) value at .044 (<0.05). The measurement of the model this study proves that is able to match with the data model of a good review. The findings of the study significant the practice impresses determination between pedagogical reasoning and the act of teaching physical education among teachers in the model equation structure. This correlates with the actual teaching phenomenon that is happening in the secondary school in Selangor.
\end{abstract}

Keywords: pedagogical reasoning, physical education and action, teaching.

Received: 24 Jan 2020 - Revised: 28 Feb 2020 - Accepted 30 March 2020 - Available online 30 June 2020

\section{INTRODUCTION}

In the face of the modernization and progress of the country, teachers' sensitivity is needed especially towards the task and responsibility of producing human capital in line with the policy of the Ministry of Education Malaysia (KPM). Certainly, career as a teacher requires a high commitment, especially the Physical Education teacher to produce a healthy, healthy student who is in line with the aspiration of the National Education Philosophy (FPK) to produce intellectual, spiritual, emotional, physical and social well-being. Therefore, in order to produce a balanced human being, the role of a teacher is important in realizing the wishes of the ministry as contained in the education philosophy.

This is in line with the National Education Philosophy (FPK) which emphasizes the elements of JERIS (physical, emotional, spiritual, intellectual and social) in developing the potential of an individual (Syed Kamaruzaman \& Shabeshan, 2013). Therefore, education will not be complete without the Physical Education subject and there is no 
quality teaching without the presence of quality teachers (Syed Kamaruzaman Syed Ali et al, 2016). This statement aims to examine and describe the quality of Physical Education teachers viewed from aspects of pedagogy, professional, personality, and social competence. Physical Education subjects also emphasize learning based on movement efficiency. Among them are games, sports, and vitality through psychomotor, cognitive, and affective domains to enhance the skills, knowledge, and values that will be used to maintain the health and well-being of students towards well-being and long life quality through the Physical Education learning experience.

Physical Education is also designed in the formal education system of the nation to develop healthy lifestyle habits among students through active involvement in physical, sports, recreational and social activities. To achieve developed nation status. Malaysia not only needs a quality educational curriculum for the purpose of producing a knowledgeable, skilled, personally talented human capital, but also a healthy and vibrant human capital to enhance the country's productivity in order to continue to be competitive internationally (Educational Policy Planning and Research Division 2006). This comprehensive Physical Education approach should be applied to all pupils starting from childhood to adolescence. This is because the Physical Education curriculum focuses on the development of psychomotor domain, cognitive, affective as well as emphasizing physical fitness to produce a holistic, healthier and vibrant young generation in the future to take on the responsibility of developing the nation towards excellence by the year 2020 (National Association for Sport and Physical Education, 2001).

It is strongly emphasized that Physical Education subjects to the overall growth and development of pupils will require efficient teaching and learning, quality teachers, teachers' knowledge and understanding. Requirements such as quality teachers can be seen in many aspects, among which are the quality of teachers in the subject matter knowledge taught by the teacher. Without a strong and proficient knowledge of how a teacher can deliver quality content to the teacher? (Rosnah Ali \& Zaharah Hussin, 2011). Similarly in contributing towards the growth and development of the students is the teaching of teachers. Teaching is the shift of knowledge from an individual to an individual or group to another group. However, the study of Shulman (1986; 1987) found that many educators were confused about what was most important in the teaching process. Is it related to teachers teaching methods, teacher management in the classroom or the discipline of the teacher itself? The study was conducted at Stanford, Shulman \& Grossman, (1988); Ball \& McDiarmid, (1990); Feiman-Nemser \& Parker, (1990), on the application of teacher knowledge which shows that much more needs to be explored and should be studied by researchers especially in the field of teaching.

Apart from efficient teaching, teacher quality and knowledge, understanding on subject matter also helps in the effectiveness of student understanding. With teachers who are knowledgeable about the content of the subject, students will be able to apply what they learn in school. This argument is backed by Fullan, (2000), which explains that teachers need to constantly improve the knowledge, skills and competencies required as the principle of teaching to be relevant to the time circulation. The content of the subjects is equally helpful in teaching the effectiveness of teachers as it refers to the identification of knowledge, understanding, attitudes and skills to be developed by teachers in the teaching of Physical Education (Bailey \& Macfadyen, 2000). In addition, the components of lesson content are the main ideas in designing for teaching (Jacobson et al, 2002). Tjeerdsma \& Metzler, (2000) also emphasize that the structure and content are an integral part of the components of a program or course. Thus, teachers need to know about the content of the subject and learn how to transfer the content to students so that students can understand it (Kauchak \& Eggan, 2003). 
Therefore, with the existence of a quality Physical Education teacher, mastering the subject matter knowledge, and pedagogy that leads to teaching and learning and can be implemented well, it can provide the students with the knowledge that the students can understand effectively and even teachers can deliver the contents of the eyes lessons are clearly in line with the curriculum requirements. Therefore, exposure to knowledge, approach and effective teaching methods as well as planning ahead before beginning the teaching process is important to ensure the teaching becomes effective and to create a conducive atmosphere in the classroom (Muhammad Faizal et al, 2014).

The Malaysian Education Development Plan (PPPM) (MOE, 2013), states that the agenda of national education policy prioritizes the construction of quality teachers as a priority. This situation is clearly embodied in KPM's main mission which aims to produce teachers with mentor mentality and always strive to carry out teacher education in parallel with other developed countries. This proves what is planned and implemented is to improve the education system in providing teachers who possess knowledge, thinking skills, bilingual proficiency, leadership skills, possessing national identity and spiritual ethics as well as being able to contribute towards the wellbeing, family, community and country.

In line with that, a teacher needs to build effective teaching and learning styles, creating a sense of excitement for learning and fostering the characteristics of professional teachers who are highly regarded by the community (Teacher Education Division, 2007). To ensure an effective teaching environment, teachers need to provide a quality teaching strategy in order to attract students to stay in the learning activities both inside and outside of the classroom. This is because the involvement of students in all activities helps them understand and master the basic skills of the game learned (Syed Kamaruzaman Syed Ali et al, 2014).
However, the task of teachers is not merely teaching the subjects taught in their respective field syllabi but communicating knowledge in their field of expertise through various teaching approaches for students to receive effective learning (Syed Kamaruzaman Syed Ali et al, (2016 ) Thus, the students can improve understanding through the process of cognition, build the skills of a skill through psychomotor movement and apply affective value through socialization activities, Julismah Jani, (2006); Paul Krome \& Erin Smith, (2006); and Rink (2013).

The Curriculum Development Division (BPK) has reviewed and enhanced the national curriculum. The review curriculum was first implemented in 2003 with emphasis on content quality as well as the foundation of effective teaching and learning strategies and is in line with today's and future educational demands (Ministry of Education 2001). Most recently, since 2011, KPM has introduced a more holistic new curriculum namely the Secondary Standard School Curriculum (KSSM) which has begun its operation in 2013 by incorporating another important element of being clamored.

The Secondary School Standard Curriculum (KSSM) Physical Education is enacted to ensure that all Malaysian students reach a set level for each content standard and learning standard in a timeframe. Knowledge, skills, and values in the Secondary School Standard Curriculum (KSSM) can be measured clearly through the established standards. However, the principle of the Integrated Curriculum of Secondary School (KBSM) is still maintained. This is because KSSM is introduced to Form 1 pupils in 2015, and now KSSM's age has reached three years in 2018. While Form 4 and 5th students are still with the Secondary School Integrated Curriculum (KBSM) and using the same syllabus and description of the lessons. One of the curricula mandatory to be followed by all pupils in primary and secondary high schools is the Physical Education curriculum (Education Act, 1996). 


\section{Mohamed Faizul Mat Som, et al. / Journal of Educational Administration Research and Review / Vol. 4 No. 1 June 2020}

Therefore, teachers are agents who are entrusted with the responsibility to take on these responsibilities. Every aspirational curriculum needs to be implemented as best as possible and wholeheartedly. The intended curriculum is the curriculum that pupils should receive, formulated based on theories of teaching and learning to produce content, pedagogy or teaching methods as well as teaching materials appropriate to the age and ability of the students (Cuban, 1992; Schmidt et al, 1996). In Malaysia, the curriculum intended for Physical Education subjects is a curriculum embodied in the Education Syllabus (Ministry of Education 1999). The Physical Education Curriculum emphasizes on education through physical activity as well as the application of noble values in individual social and emotional (Lumpkin, 2002; Lutan, 2001. The contribution of quality Physical Education not only helps the student to become active, but also improves their thinking and beliefs while also contributing to the health and well-being of a child's development. Emphasis on meeting individual growth and development needs to create a vibrant, prosperous and productive society (Darst \& Pangrazi, 2006; Gallahue, 1996; are also contained and in line with National Education Philosophy (FPK).

This theory and model are considered the best conceptual framework for identifying and understanding teacher skills, empirical data analysis, allowing documentation and knowledge exchange of knowledge related to teaching practice (Carmen Fernandez, 2013) Thus, based on Shulman, (1987) model, developed by Grossman, (1990), the researcher applied dimensions in this study such as (i) understanding; (ii) transformation; (iii) teaching; (iv) assessment; (v) reflection and (vi) new understanding. Therefore, this study was conducted to describe the level of practice of pedagogical reasoning and teaching activities of the Klang Physical Education teacher. Hence, the outcome of this study can be used as a guide in efforts to uplift the Physical Education subject at the national level and be shared with schools in the districts and other states in Malaysia.

\section{METHODS}

This study was carried out using a quantitative approach that was descriptive design using questionnaire. The variables in this study are understanding, transformation and teaching of teachers as exogenous variables with nine pedagogical practice practice building which is comprehension is the content, while the transformation dimension is the preparation and effort of teachers. Methods, management and discipline in the teaching domain. The new assessment, reflection and understanding of the teacher as an endogenous variable with seven sub-dimensions namely student progress, collecting information, improvements, notes, discussions, documentation and analysis.

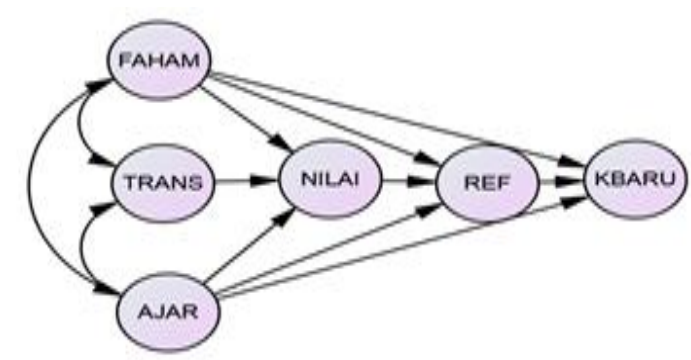

Figure 1: A Priori Model

A total of 580 secondary school Physical Education teachers in the district of Klang, Selangor were asked to complete a questionnaire comprising measurements involving the practice of pedagogy and teacher teaching. The questionnaire was distributed to respondents using simple random sampling method. Approach to test the practice of teaching Physical Education teacher. Understanding dimensions (15 items), transformation (12 items), teaching (25 items), evaluation (11 items), reflection (11 items) and new understanding domain (8 items) and the number of items that respondents need to answer are 82 items as a whole. All questions using the 5 points likert scale as item measurement $(1=$ very disagreeable, $2=$ disagree, $3=$ quite agree, $4=$ agree and $5=$ strongly agree).

This research instrument used questionnaire as the main tool of study. The research instrument used in this study was a combination of set of 
questionnaires modified from the Teachers InDepth Content Knowledge: Definition and Check List questionnaire (Shulman 1992) and Technological Pedagogical Content Knowledge (TPACK): The Development and Validation of an Assessment Instrument for Preserve Teachers (Schmid et al, 2009) and Muhammad Faizal et al, (2014). In this study the items constructed were based on the constructs of each idea in the conceptual framework of pedagogical knowledge of content based on the Circular of Pedagogical of Reasoning and Action Model which has six constructs as previously mentioned. It has been applied in previous studies of Grossman, (1999).

\section{RESULTS AND DISCUSSION}

\section{A. Results}

The reliability of the question items is .89 and the normality distribution is that all of these dimensions are normalized. The validation factor analysis (CFA) was conducted to all six study variables. CFA is performed to test the model's compatibility with collected and collected data (Brown et al, 2006). The use of CFA in the construction and validation of instrument items is particularly appropriate and appropriate for constructing an empirically certified inventory to measure pedagogical practices and teaching practices of Physical Education teachers in the State of Selangor. There are several coefficients used to measure the fit of the model with the study data ( $\mathrm{Hu} \&$ Bentler, 1999). The compatibility index used in this study was CMIN / DF, comparative fit Index (CFI). For Root Mean Square Error of Approximation (RMSEA) value is $.8-.10$ (MacCallum et al, 1996). Therefore, the model that meets the criteria of the coefficient will not be rejected. This CFA has been implemented using the AMOS version 21 software, aimed at testing the existence of unidimensionality for each dimension on all variables of understanding, transformation, teaching, evaluation, reflection and new understanding.

The compatibility index of CMIN, CFI, TLI and RMSEA in the Comparison baseline table is from .941 to .951 for this model. The value of correspondence exceeding .90 confirms the decision of Two Power of Goodness of Fit that the model of measurement of the pedagogical reasoning practice model and the teacher's teaching action proposed by the researcher corresponds to the study data.

Referring to the table above shows the precision of the measurement model of the measurement. The figure and table describes the Goodness of fit Chi Square test with the degree of freedom 725 is 1666.704, CMIN / DF is $2.299(<5)$, Comparative Fit Index $(\mathrm{CFI})$ is $.951(>.90)$, and Goodness of fit Index (GFI) is .941 (> .90). Measurement model has been able to explain the existence of model matching and research data. The results of the Maximum Likelihood Estimates analysis in Table 3 show that teachers teaching Physics do not practice the relationship between FAHAM and REF, and TRANS with VALUE.

While the Squared Multiple Correlations results in table 6 below show the variance values for VALUE, REF and KBARU predicted by the variable indicator in fitting model (squared multiple correlations) for VALUE is .619, REF .524 and KBARU are $.623)$. This means that $61.9 \%$ of the variance later in the VALUE can be predicted by the indicator variable, as well as latern variance for REF and KBARU also predictable with $52.4 \%$ and $62.3 \%$. Therefore, Squared Multiple Correlations results also show variance values for all indicator variables in the model. In this case, .524 to .623 (52.4\% to $62.3 \%$ variance in indicator variables in the structural equation model can be predicted by the study data.

Figure 4 and 5 below is the Measurement Model before the CFA (Confirmatory Factor Analysis). Before and after the CFA was done for item verification, the researchers found that there were some items that need to be removed based on outlier through (Mahalanobis distance) and EFA in modification Modification Indices (MI) and Standardized Regression Weight. While the third figure is the full size measurement model of the item after the CFA. 
The compatibility index of CMIN, CFI, TLI and RMSEA in the Comparison baseline table is from .989 to .993 for this model. The value of correspondence exceeding .90 confirms the decision of Two Power of Goodness of Fit that the structure model of measurement of the pedagogical reasoning practice model and the teacher's teaching action proposed by the researcher corresponds to the study data.

Referring to the table above shows the precision of the measurement model of the measurement. The figure and table describes the Goodness of fit Chi Square test with the degree of freedom 53 is 111.298, CMIN / DF is $2.100(<5)$, Comparative Fit Index $(\mathrm{CFI})$ is .993 ( $>$.90), and Goodness of fit Index (GFI) is .989 (> .90) and RMSEA value is .044. Measurement of structure model has been able to explain the existence of model matching and research data

Table 1: Profile of Respondents for Secondary Physical Education Teacher

\begin{tabular}{|c|c|c|}
\hline Item & Respondent Teacher & Percentage (\%) \\
\hline Sex & $\mathbf{N}$ & $\%$ \\
\hline Man & 208 & 45.6 \\
\hline Women & 372 & 54.4 \\
\hline Total & 580 & 100.0 \\
\hline Etnic & $\mathbf{N}$ & $\%$ \\
\hline Malay & 529 & 91.5 \\
\hline Indian & 31 & 5.2 \\
\hline Chinese & 16 & 2.7 \\
\hline Other & & \\
\hline Total & 580 & 100.0 \\
\hline Age & $\mathbf{N}$ & $\%$ \\
\hline Below 25 years old & 50 & 5.0 \\
\hline 26-30 years old & 95 & 15.9 \\
\hline 31-35 year old & 175 & 32.7 \\
\hline $35-40$ years old & 126 & 21.6 \\
\hline More than 40 years old & 134 & 24.8 \\
\hline \multirow[t]{2}{*}{ Total } & 580 & 100.0 \\
\hline & & e \\
\hline Academic Qualification & $\mathrm{N}$ & $\%$ \\
\hline SPM/STPM & 10 & 1.7 \\
\hline Diploma & 12 & 2.0 \\
\hline First Degree & 524 & 90.6 \\
\hline Master & 34 & 5.7 \\
\hline Total & 597 & 100.0 \\
\hline Profesional Qualification & $\mathrm{N}$ & $\%$ \\
\hline Certificate of College & 35 & 5.9 \\
\hline Diploma of College/KPLI & 228 & 38.2 \\
\hline Degree of College & 256 & 42.9 \\
\hline Master of Education & 61 & 13.1 \\
\hline Total & 580 & 100.0 \\
\hline School Category & $\mathrm{N}$ & $\%$ \\
\hline City & 357 & 59.8 \\
\hline Rural & 223 & 40.2 \\
\hline Jumlah & 580 & 100.0 \\
\hline Specific & $\mathbf{N}$ & $\%$ \\
\hline Physical Education & 202 & 33.8 \\
\hline Sport Science & 60 & 12.9 \\
\hline others & 31 & 53.3 \\
\hline Total & 580 & 100.0 \\
\hline Teaching Experience & $\mathbf{N}$ & $\%$ \\
\hline Below 10 year old & 302 & 50.6 \\
\hline
\end{tabular}
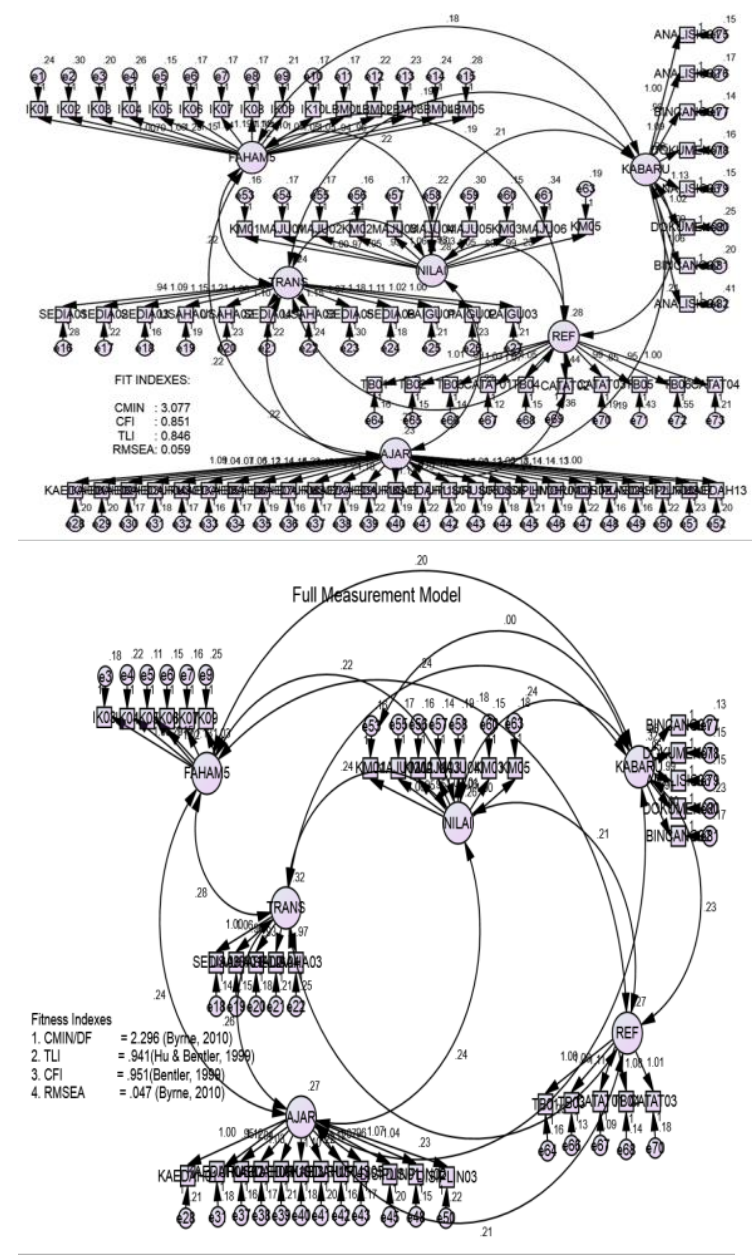

Figure 3: Full Measurement Model

Table 2: Measurement Accuracy Matching Model.

\begin{tabular}{lllcccc}
\hline & & & Estimate & SE & CR & P \\
\hline PENILAIAN & $<--$ & PENGAJARAN & .246 & .056 & 4.383 & $* * *$ \\
PENILAIAN & $<--$ & TRANSFORMASI & .121 & .107 & 1.137 & .256 \\
PENILAIAN & $<--$ & KEFAHAMAN & .146 & .045 & 3.256 & .001 \\
REFLEKSI & $<---$ & PENILAIAN & .392 & .109 & 3.605 & $* * *$ \\
REFLEKSI & $<--$ & KEFAHAMAN & .014 & .051 & .281 & .779 \\
REFLEKSI & $<---$ & PENGAJARAN & .206 & .056 & 3.696 & $* * *$ \\
KEFAHAMAN & $<--$ & REFLEKSI & .127 & .059 & 2.134 & .033 \\
BAHARU & & & & & & \\
KEFAHAMAN & $<--$ & PENGAJARAN & .215 & .036 & 5.980 & $* * *$ \\
BAHARU & & & & & & \\
KEFAHAMAN & $<--$ & \multirow{2}{*}{ KEFAHAMAN } & .081 & .032 & 2.496 & .013 \\
BAHARU & & & & & & \\
\hline
\end{tabular}

Table 3: Square Multiple Correlation

\begin{tabular}{lc}
\hline & Estimate \\
\hline PENILAIAN & .619 \\
REFLEKSI & .524 \\
KEFAHAMAN & .623 \\
BAHARU & \\
\hline
\end{tabular}

Figure 2: Measurement Model Item Level

Model Practice of Pedagogical Reasoning and Action Teaching in The Secondary School Physical Education Teachers in Selangor| 93 


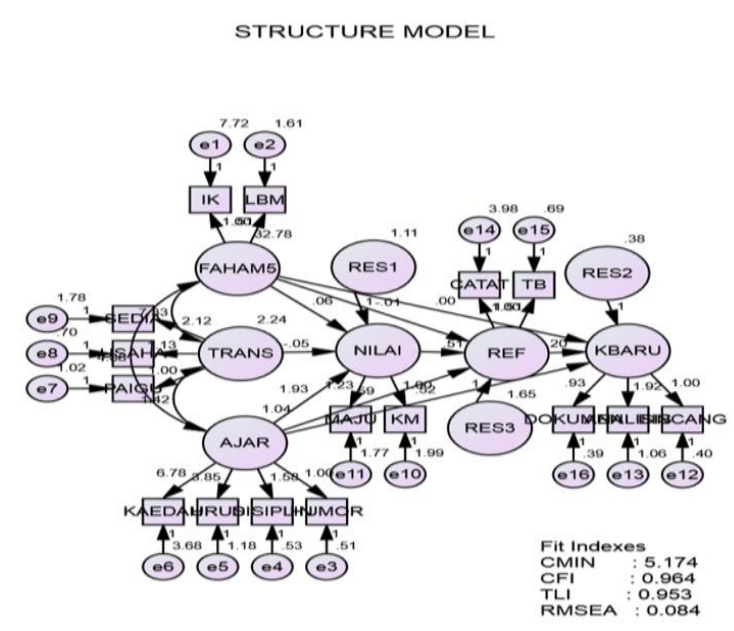

Figure 4: Structure Model

STRUCTURE MODEL (AFTER SCREENING)

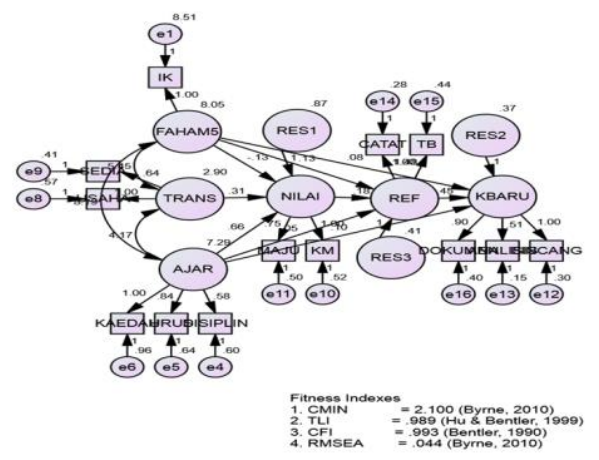

Figure 5: Structure Model After Screening

Table 4: Specify the Accuracy of the Structural Model Matching

Specify the Accuracy of the Structural Model Matching

\begin{tabular}{cccc}
\hline Index & $\begin{array}{c}\text { Value Index } \\
\text { Accepted }\end{array}$ & $\begin{array}{c}\text { Before Reaching } \\
\text { Match Accuracy }\end{array}$ & $\begin{array}{c}\text { After Reaching } \\
\text { Match Accuracy }\end{array}$ \\
\hline$\chi 2 / \mathrm{df}$ & & & \\
CMIN & $<5$ & 1.030 & $\mathbf{2 . 1 0 0}$ \\
P & .00 & .00 & .00 \\
CFI (Comparative Fit & $>.90$ & .998 & .993 \\
Index) & & & \\
TLI ( Tucker Lewis & $>.90$ & .998 & .989 \\
Index) & & & \\
RMSEA (Root Mean & $<.05$ & .016 & $\mathbf{0 4 4}$ \\
Square Error of & & & \\
Approximation) & & & \\
\hline
\end{tabular}

\section{B. Discussion}

The findings show that the measurement model for the six dimensions corresponds to the study data and explains that all the indicators used are significant predictors. The findings of this study also found that the findings support the pedagogical knowledge theory of the content presented by Shulman (1986) and the pedagogical and behavioral reasoning model (1987). This is because the model can be translated by the researcher by adapting in writing and research can also translate the model in the teaching of Physical Education subjects. In addition to the Shulman model, researchers also use the Le Francois Model (1992) with emphasis on objectives, goals, students' readiness, determining teaching strategies and evaluation. Combining and underlying these two theories ensures success in the process of practice of pedagogy and teaching of Physical Education teachers. Based on the model adopted by this researcher, it is found that Physical Education teachers should implement transformation or change and self and change the notion of the importance of effective teaching through the Model Practice of Pedagogical Reasoning and Action Teacher (MPPRA) practice dimension.

The findings of this study indicate that Physical Education teachers do not exercise good judgment and reflection based on the model of the demonstration. It is likely that GPJ often goes out of school to manage and become a sports coach at the MSSD (District), MSS (State) and MSSM (National) level. The absence at school has implications for postreflection reflection and assessment, whether assessment of SEGAK and BMI or assessment in the examination. Implications also occur in checking the assignments as well as test papers and student examinations due to limited time limitations and the timing of submission of marks to class teachers. Therefore, there is a lack of student performance. The results of this study also show that there is inconsistency between the state and the ministry. It is based on the findings made by the researcher. PITO needs to be continued and improved at the district and state level so that information about pedagogy and teacher appraisal practices is aligned to continue the legacy of teaching excellence.

Model Practice of Pedagogical Reasoning and Action Teaching in The Secondary School Physical Education Teachers in Selangor| 94 
This theory and model are considered the best conceptual framework for identifying and understanding teacher skills, empirical data analysis, allowing documentation and knowledge exchange of knowledge related to teaching practice (Carmen Fernandez, 2013) Thus, based on Shulman, (1987) model, developed by Grossman, (1990), the researcher applied dimensions in this study such as (i) understanding; (ii) transformation; (iii) teaching; (iv) assessment; (v) reflection and (vi) new understanding. Therefore, this study was conducted to describe the level of practice of pedagogical reasoning and teaching activities of the Klang Physical Education teacher. Hence, the outcome of this study can be used as a guide in efforts to uplift the Physical Education subject at the national level and be shared with schools in the districts and other states in Malaysia.

\section{CONCLUSION/RECOMENDATION}

The findings show that the measurement model for the six dimensions corresponds to the study data and explains that all the indicators used are significant predictors. The findings of this study also found that the findings support the pedagogical knowledge theory of the content presented by Shulman (1986) and the pedagogical and behavioral reasoning model (1987). This is because the model can be translated by the researcher by adapting in writing and research can also translate the model in the teaching of Physical Education subjects. In addition to the Shulman model, researchers also use the Le Francois Model (1992) with emphasis on objectives, goals, students' readiness, determining teaching strategies and evaluation. Combining and underlying these two theories ensures success in the process of practice of pedagogy and teaching of Physical Education teachers. Based on the model adopted by this researcher, it is found that Physical Education teachers should implement transformation or change and self and change the notion of the importance of effective teaching through the Model Practice of Pedagogical Reasoning and Action Teacher (MPPRA) practice dimension.
The findings of this study indicate that Physical Education teachers do not exercise good judgment and reflection based on the model of the demonstration. It is likely that GPJ often goes out of school to manage and become a sports coach at the MSSD (District), MSS (State) and MSSM (National) level. The absence at school has implications for postreflection reflection and assessment, whether assessment of SEGAK and BMI or assessment in the examination. Implications also occur in checking the assignments as well as test papers and student examinations due to limited time limitations and the timing of submission of marks to class teachers. Therefore, there is a lack of student performance. The results of this study also show that there is inconsistency between the state and the ministry. It is based on the findings made by the researcher. PITO needs to be continued and improved at the district and state level so that information about pedagogy and teacher appraisal practices is aligned to continue the legacy of teaching excellence.

The alignment of this teaching model should be strengthened starting at the school, but teachers who are sent to the course must be in line with their needs, skills, interests and knowledge. As such, it is not only to increase the burden of teachers and to fill vacancies alone, as well as the coordination and alignment of duties among all parties in implementing effective teaching practices. Therefore, the Physical Education teacher needs to be alert in facing the current changes and the transformation of national education by having the spirit of continuing study, preparing to attend courses in service or option-added intervention programs (PITO) to enhance pedagogical skills and understanding of subject matter content.

The summary of the research may be provided in a brief section Conclusion, which can be separate section or a subsection of Discussion or Results and Discussion section. The Conclusion section should lead the reader to the important issues of the article. It can also be followed by suggestions or recommendations relating to the subsequent research. 


\section{ACKNOWLEDGMENTS}

With all due respect and thanks, I record to Dr. Shahrir Bin Jamaluddin and Dr. Syed Kamaruzaman Bin Syed Ali, as my supervisor who has been very helpful, provided insight, guidance, advice, encouragement and motivation from the very beginning to the completion of writing this study. A special thank you to our beloved wife, Razila Bt $\mathrm{Hj}$ Kasmin, as well as the children of heirs to the good of father and mother, Auni Zabirah, Aufa Nabilah, Muhammad Amsyar Hakimi, Aura Batrisyia and Bazla Humaira. I hope you can take some inspiration in your quest for knowledge. Harness and mother $\mathrm{Hj}$. Mat Som Bin Samurmin and Hjh. Tuminah Bt Mahmod thank you for the prayers, love and always willing to help my children in their quest for knowledge. Thank you also to my mother-inlaw Hjh Shariah Bt Surat and Hj. Kasmin Bin,Sarbini may Allah place a horde on those who believe and do good deeds. A special thank you to the Ministry of Education Malaysia, Department of Education for providing me with the opportunity to continue my studies with the Full Scholarships With No Scholarship (CBBPTB). May this writing be a guide and a blessing to all. Thank you.

\section{REFERENCES}

Akta Pendidikan 1996 (Akta 550) \& peraturan-peraturan terpilih hingga 20 hb. Julai 2006. Kuala Lumpur. ILBS.

Bailey, R., Macfadyen, T. (2000). Teaching physical education 5-11. London: Continuum.

Ball, D.L., \& MacDiarmid, G. (1990). The subject matter preparation of teachers.Dalam W. Houston., M. Huberman., \& J. Sikula. (Eds.) Handbook of reasearch on Teacher Education, hlm. 437449, New York: MacMillan.

Brown, T.A (2006). Comfirmatory factor anlysis for applied research. New York: The Giuford Press.

Carmen Fernandez (2014). Knowledge base for teaching and pedagogical content knowledge (PCK): Some useful models and implications for teachers' training.

Cuban, L. (1992).Curriculum stability and change.

Darst, P.W., \& Pangrazi, R.P. (2006). Dynamic physical education for secondary school student $\left(5^{\text {th }}\right.$ ed.). Massachusetts: Allyn \& Bacon.
Feiman-Nemser, S., \& Parker, M.B. (1990). Making subject matter part of the conversation in learning to teach. Journal of Teacher Education, 41(3), hlm. 32-43.

Fullan, M., \& Mascall, B. (2000). Human resourse issues in education: A literature review, Wellington: New Zealand Ministry of Education.

Gallahue, D. L. (1996). Developmental physical education for today's children (3rd ed.). Dubuque, IL: Brown \& Benchmark.

Gallahue, D.L. (1996). Develeopmental physical education for today's children. Boston: McGraw Hill.

Hu, L; \& Bentler, P.M; (1999). Cutoff of criteria for fit indices in covariance structure analysis: Conventional criteria versus new alternative. Structural Equation Modelling, 6, 1-55.

Jacobsen, D.A., Eggen, P., \& Kauchak, D. (2002). Methods for teaching. Promoting students learning. $6^{\text {th }}$ edition. Ohio: Merill Prentice Ha

Johnson, R., B., \& Christensen, L. B. (2008). Educational research: Quantitative, qualitative and mixed approaches. Thousand Oaks: Sage Publications.

Julismah Jani (2006). Teras pengetahuan mengajar guru mata pelajaran pendidikan jasmani di Sekolah Menengah Daerah Batang Padang, Perak. Jabatan Sains Sukan, Fakulti Sains Kognitif dan Pembangunan Manusia. UPSI.

Kauchak, D.P., \& Eggen, P.D (2003). Learning and teaching. Research-based methods. Fourth Edition. Boston: Pearson Education

Kementerian Pelajaran Malaysia (1999). Surat pekeliling ikhtisas bil. 3/1999: Pendidikan jasmani. Kuala Lumpur: Bahagian Sekolah.

Kementerian Pelajaran Malaysia. (2007). Pelan Induk Pembangunan Pendidikan 2006- 2010. Putrajaya: Bahagian Perancangan dan Penyelidikan Dasar Pendidikan.

Kementerian Pendidikan Malaysia. (2001). Kepimpinan dan pengurusan kurikulum di sekolah. Pusat Perkembangan Kurikulum. Kuala Lumpur

Lumpkin, A. (2002). Introduction to physical education, exercise science, and sport studies (5th ed.). USA: McGraw-Hill.

Lutan, Rusli. (2001). Asas-asas pendidikan jasmani. Pendekatan pendidikan gerak di sekolah dasar. Jakarta: Direktokrat Jeneral Olahraga, Depdiknas.

MacCallum, R. C., Widaman, K. F., Zhang, S., \& Hong S. (1999). Sample size in factor analysis. Psychological Methods, 4, 84-9

Muhammad Faizal A. Ghani, Faisol Elham, Zulkifli Awang, \& Shahril@Charil Marzuki (2014). Pengajaran mata pelajaran pendidikan jasmani

Model Practice of Pedagogical Reasoning and Action Teaching in The Secondary School Physical Education Teachers in Selangor| 96 


\section{Mohamed Faizul Mat Som, et al. / Journal of Educational Administration Research and Review / Vol. 4 No. 1 June 2020}

di sekolah menengah kawasan bandar dan luar bandar: Perspektif murid. Jurnal Kepimpinan Pendidikan, Universiti Malaya, 1(3): 54-74.

Muhammad Faizal A. Ghani, Norfariza Mohd Radzi, Simin Ghavifekr, Husaina Banu Kenayatullah dan Mokhtar Muhamad (2014). Pengurusan disiplin murid di sekolah kawasan bandar dan luar bandar: Perspektif pemimpin sekolah. Jurnal Kepimpinan Pendidikan, Universiti Malaya, 1(1): 7-40.

Pelan pembangunan pendidikan Malaysia 2013-2025. Bil. 5/2015. Kementerian pendidikan Malaysia.

Rink, J., Hall, T., dan Williams, L. (2010). Schoolwide physical activity - A comprehensive guide to designing and conducting programs. IL, USA: Human Kinetics Publisher Inc.

Rosnah Ali \& Zaharah Hussin (2011). Kualiti guru pendidikan islam dalam ilmu pengetahuan isi kandungan mata pelajaran pendidikan Islam. Jurnal Pendidikan (Edisi Khas), 2011, Universiti Malaya: Kuala Lumpur.

Schmidt et.al, (2009). Technological pedagogical content knowledge (TPACK): The development and validation of an assessment instrument for preservice teachers. Paper presented at the 2009 Annual meeting of the American educational research association. April 13-17, San Diego, California.

Schmidt, W.H., Jorde, D., Cogan,L.S., Barrier,E., Gonzalo,I.,Schimizu, K.,Sawasa,T., Valverde,G.A., McKinght, C., Prawat, R.S., Wiley,D., Raizen,S.A., Britton,E.D., Wolfe, R.G. (1996). Characterizing pedagogical flow. An investigation of mathematics and science teaching in six countries. The Netherlands Kluwer Academic Publishers.

Shulman, L. S. (1987). Knowledge and teaching: Foundations of the new reform. Harvard Educational Review, 15(2), 4-14.
Shulman, L.S (1986). Those who understand: Knowledge growth in teaching. Education Researcher, 15(2), hlm. 4-14.

Shulman, L.S (1992). Ways of seeing, ways of knowing, ways of teaching, ways of learning about teaching. Journal of Curriculum studies, 28, Sept-Oct. hlm. 393-396

Shulman, L.S, \& Sparks, D. (1992). Merging content knowledge and pedagogy: An interview with Lee Shulman. Journal of staff Develpopment, 13(1), hlm. 14-16.

Shulman, L.S. (1987). Knowledge and teaching: Foundations of the new reform. Harvard Educational Review, 57 (1), hlm. 1-22

Shulman, L.S., \& Grossman, P.L. (1988). The intern teacher case book. San Franscisco, CA: Far Wets Laboratory for Educational Research and Davelopment.

Syed Kamaruzaman Syed Ali \& Shabeshan Rengasamy (2013). Strategi dan perancangan dalam pengajaran Pendidikan Jasmani di sekolah menengah dalam Amalan Pendidikan Jasmani di Malaysia. Petaling Jaya: Pearson

Syed Kamaruzaman Syed Ali, Hazmaniran Harun, Farrawahida Mahmad Mddim \& Habib Mat Som (2014). Pendidikan Jasmani dan Kesihatan Sekolah Menengah Di Malaysia: Halangan dan Cabaran Dalam Pelaksanaan Pentaksiran Berasaskan Sekolah (PBS). Jurnal isu dalam pendidikan 2014. Universiti Malaya.

Syed Kamaruzzaman, Habib Mat Som \& Muhamad Akhbar Zahidi (2016). Transformasi pendidikan jasmani: Satu anjakan pengajaran berkualiti: halaman 249 \& 251 dalam transfomasi pendidikan nasional antara aspirasi dan anjakan.Kuala Lumpur: Penerbit Universiti Malaya.

Tjeerdsma, B.L., \& Metzler. M.W. (2000). Making decision for program improvement. Journal of teaching in Physical education. 19. 538-542 